\title{
Olfactory Wiring Logic in Amphibians Challenges the Basic Assumptions of the Unbranched Axon Concept
}

\author{
Thomas Hassenklöver ${ }^{1,2}$ and Ivan Manzini ${ }^{1,2}$ \\ ${ }^{1}$ Institute of Neurophysiology and Cellular Biophysics, University of Göttingen, 37073 Göttingen, Germany, and ${ }^{2}$ Center for Nanoscale Microscopy and \\ Molecular Physiology of the Brain, 37073 Göttingen, Germany
}

Olfactory receptor neurons extend axons into the olfactory bulb, where they face the challenge to integrate into existing circuitry. The consensus view is that in vertebrates individual receptor neurons project unbranched axons into one specific glomerulus of the olfactory bulb. We report here that, strikingly different from the generally assumed wiring principle in vertebrate olfactory systems, axons of single receptor neurons of Xenopus laevis regularly bifurcate and project into more than one glomerulus. Specifically, the innervation of multiple glomeruli is present in all ontogenetic stages of this species, from the larva to the postmetamorphic frog. Also, we show that this unexpected wiring pattern is not restricted to axons of immature receptor neurons, but that it is also a feature of mature neurons of both the main and accessory olfactory system. This glomerular innervation pattern is unique among vertebrates investigated so far and represents a new olfactory wiring strategy.

\section{Introduction}

In the vertebrate main olfactory epithelium (MOE), olfactory receptor neurons (ORNs) express a single allele of the entire odorant receptor (OR) gene repertoire (Chess et al., 1994; Malnic et al., 1999; but see Ishii and Mombaerts, 2011), and ORNs expressing the same OR send their axons to the main olfactory bulb (OB) and coalesce into at most a few glomeruli (Mombaerts, 2006). Thereby, each ORN sends a single, unbranched axon to only a single glomerulus in the OB (Klenoff and Greer, 1998; for review, see Lodovichi and Belluscio, 2012). Within glomeruli, ORN axons establish synaptic contacts to mitral cells, second-order neurons that project to higher olfactory centers (Komiyama and Luo, 2006). Generally, in teleost fish, amphibians, and reptiles, individual mitral cells extend several primary dendrites into multiple, spatially separated glomeruli (Dryer and Graziadei, 1994). In later diverging vertebrates, mitral cells usually possess only one primary dendrite innervating a single glomerulus and multiple secondary dendrites (Dryer and Graziadei, 1994).

Most tetrapods also possess an accessory olfactory system (Eisthen, 1992), mainly involved in the detection of pheromones. Phylogenetically, it first evolved in amphibians (Eisthen, 1992; but see González et al., 2010). In rodents, vomeronasal receptor

\footnotetext{
Received June 28, 2013; revised Aug. 16, 2013; accepted Sept. 17, 2013.

Author contributions: T.H. and I.M. designed research; T.H. performed research; T.H. analyzed data; T.H. and I.M. wrote the paper.

This work was supported by DFG Schwerpunktprogramm 1392 to I.M. and Cluster of Excellence and DFG Research Center Nanoscale Microscopy and Molecular Physiology of the Brain to I.M. We thank Dr. Sigrun I. Korsching for the critical reading of an earlier version of this manuscript.

The authors declare no competing financial interests.

Correspondence should be addressed to Dr. Ivan Manzini, Center for Nanoscale Microscopy and Molecular Physiology of the Brain, Institute of Neurophysiology and Cellular Biophysics, University of Göttingen, Humboldtallee 23, 37073 Göttingen, Germany. E-mail: imanzin@gwdg.de.

DOI:10.1523/JNEUROSCI.2755-13.2013

Copyright $\odot 2013$ the authors $\quad 0270-6474 / 13 / 3317247-06 \$ 15.00 / 0$
}

neurons (VRNs) expressing a given vomeronasal receptor (VR), do not coalesce into only few glomeruli but project their unbranched axons into up to 30 glomeruli of the accessory OB (Del Punta et al., 2002). Individual mitral cells project multiple dendrites to several glomeruli receiving input from VRNs (Wagner et al., 2006; Meeks et al., 2010).

Developing neuronal and sensory networks undergo substantial refinement and pruning of axons and synaptic connections (Shatz, 1996). To our knowledge, the only study investigating the growth and maturation of individual, clearly identified ORN axons was conducted in zebrafish embryos (Dynes and Ngai, 1998). It showed that individual ORNs elaborate unbranched axons projecting directly to their target glomerulus. Also in rodents, individual ORN axons innervate one specific glomerulus, and initial exuberant intraglomerular arborizations and synaptic contacts are gradually reduced (Marcucci et al., 2011).

In contrast to zebrafish and mice, and contrary to the consensus view, in a restricted developmental phase of larval $\mathrm{Xe}$ nopus laevis, individual ORNs project into more than one glomerulus (Nezlin and Schild, 2005). Here we show that innervation of multiple glomeruli by single ORN axons is not restricted to immature ORNs and that it is present also in the accessory olfactory system. Furthermore, this unexpected glomerular innervation pattern is not a developmental, larval feature but is retained in postmetamorphic animals. A similar glomerular innervation pattern is not known in any other vertebrate species so far, and represents a new olfactory wiring strategy.

\section{Materials and Methods}

Whole-mount $O B$ preparation. Larval X. laevis (of either sex, stages 51-54) (Nieuwkoop and Faber, 1994) were chilled in iced water and killed by transection of the spinal cord. Animal handling and experiments were performed as approved by the Göttingen University Com- 
mittee for Ethics in Animal Experimentation. A block of tissue containing the olfactory epithelia, the olfactory nerves, and the anterior part of the brain was dissected and transferred to frog saline (98 mм NaCl, 2 mм KCl, $1 \mathrm{~mm} \mathrm{CaCl}_{2}, 2 \mathrm{~mm} \mathrm{MgCl}_{2}, 5 \mathrm{~mm}$ glucose, $5 \mathrm{~mm}$ Na-pyruvate, $10 \mathrm{~mm}$ HEPES; $230 \mathrm{mOsmol} / \mathrm{L}, \mathrm{pH} 7.8$ ). The connective tissue covering the ventral part of the brain was removed to expose the olfactory nerves and the anterior telencephalon. Postmetamorphic frogs (stage $66+$ ) were chilled in iced water and killed by decapitation. The brain and the olfactory nerves were ventrally exposed by removing the skull and connective tissue using fine scissors in frog saline.

Sensory neuron labeling via electroporation. Fluorophore-coupled dextrans (Alexa-488 $3 \mathrm{kDa} / 10 \mathrm{kDa}$ dextran, Alexa-546 $10 \mathrm{kDa}$ dextran, Alexa-568 $10 \mathrm{kDa}$ dextran, Alexa-594 $10 \mathrm{kDa}$ dextran; Invitrogen) or plasmid DNA, encoding for AcGFP (Clontech), were introduced into sensory neurons via electroporation (Haas et al., 2002). For anterograde labeling in postmetamorphic animals, tetramethylrhodamine and biotin-conjugated dextran was used (micro-Ruby; Invitrogen). Specimens were anesthetized in $0.02 \%$ MS-222 (ethyl 3-aminobenzoate methanesulfonate; Sigma-Aldrich). For sparse labeling, patch pipettes (resistance $\sim 3-15 \mathrm{M} \Omega$ ) pulled from borosilicate glass capillaries (Hilgenberg) were filled with fluorophore-coupled dextrans (3 mM in frog saline) or plasmid DNA $(1 \mu \mathrm{g} / \mu \mathrm{l})$ and introduced into olfactory sensory epithelia under the control of a micromanipulator. An electrode inside the pipette and a bath electrode in contact with the tail of the tadpole were connected to a voltage pulse generator (ELP-01D, NPI Electronics). One voltage pulse ( $20 \mathrm{~V}, 25 \mathrm{~ms}$ duration) was applied.

To stain all sensory neurons, crystals of fluorophore-coupled dextrans were introduced into both nasal cavities and dissolved in the residual moisture. Two thin platinum electrodes were carefully introduced into the nasal cavities. The electrodes were connected to a voltage pulse generator, and 12 pulses $(20-25 \mathrm{~V}, 25 \mathrm{~ms}$ duration at $2 \mathrm{~Hz}$ ) with alternating polarity were applied. Labeled cells were examined using an upright confocal laser-scanning microscope (LSM 780/Axio Examiner with spectral detector, Carl Zeiss) after at least $24 \mathrm{~h}$ after electroporation.

Olfactory neurons of postmetamorphic animals were labeled by introducing a dye-filled patch pipette into the exposed olfactory nerve and by applying a single voltage pulse $(20 \mathrm{~V}, 25 \mathrm{~ms}$ duration). At least $1 \mathrm{~h}$ after electroporation, the axon terminals in the $\mathrm{OB}$ could be visualized using confocal laser-scanning microscopy.

In vivo time lapse imaging. X. laevis albino larvae (stages 45-54) with individually labeled ORNs were anesthetized, and the OB was imaged in vivo with an upright confocal laser-scanning microscope (see above) in intervals of 2 to $3 \mathrm{~d}$. Animals were kept individually in separate water tanks between measurements in reduced light conditions.

Image processing and data evaluation. Multilabeled samples were acquired as $\lambda$ stacks, and overlapping label fluorescence and/or tissue autofluorescence emission spectra were separated using linear unmixing algorithm (ZEN Software, Carl Zeiss). Acquired image stacks are presented as maximum intensity projections. Some in vivo recordings were filtered to reduce noise (Coupé et al., 2012). Axonal morphology was manually reconstructed using assisted filament drawing in Imaris (Bitplane). Axon length was measured from the apical border of the OB to glomerular tufts. Values are presented as mean \pm SEM.

\section{Results}

Coarse topology of ORN and VRN axonal projections

To follow the growth pattern of ORNs and VRNs, we stained defined groups of neurons with fluorophore-coupled dextran dyes via electroporation at different locations in the epithelia of the olfactory organ. As expected, all ORNs terminated in the main $\mathrm{OB}$ (Fig. 1A, green, yellow, and red projections), and all VRNs exclusively terminated in the accessory OB (Fig. 1A, orange projections). The main $\mathrm{OB}$ is separated into a lateral, intermediate, and medial glomerular cluster (Fig. 1C) (Gliem et al., 2013). ORNs residing in the lateral, intermediate, and medial MOE generally terminated into the corresponding glomerular cluster, respectively, some overlap notwithstanding.

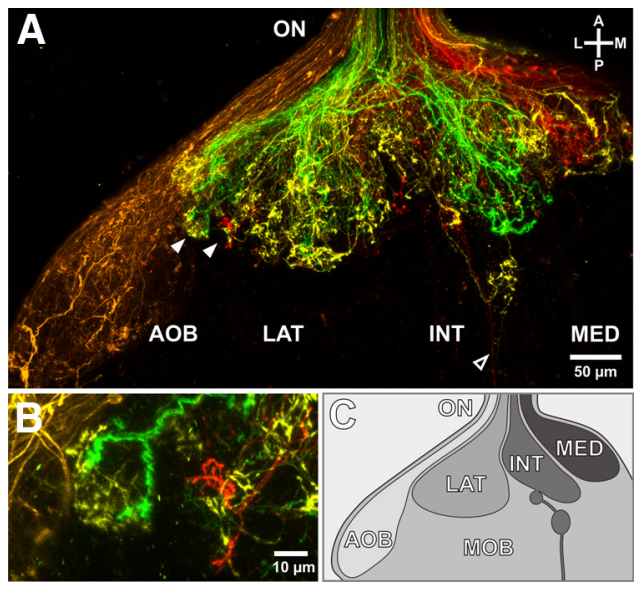

Figure 1. Visualization of axonal projections of ORNs and VRNs. $\boldsymbol{A}$, Sparse labeling of olfactory sensory neurons reveals the structure of the $O B$ (only one $O B$ hemisphere is depicted). Different colors represent different labeling sites in the nose: orange represents VNO; green, lateral part of the MOE; yellow, intermediate part of the MOE; red, medial part of the MOE. The accessory $O B$ is a clearly separated structure receiving only vomeronasal input. The different glomerular clusters of the main $O B$ show a considerable amount of overlap between inputs from the individual labeling sites in the MOE. Some axons from the intermediate cluster bypass and leave the $O B$ in caudal direction (open arrowhead). $\boldsymbol{B}$, Individual glomeruli with axonal inputs from different locations in the nose can be identified (see also $\boldsymbol{A}$, filled arrowheads). $\boldsymbol{C}$, Schematic representation of the accessory and the main $0 B$, which separates into a lateral, intermediate, and medial cluster. $A 0 B, A c c e s s o r y$ $O B$; INT, intermediate glomerular cluster; LAT, lateral glomerular cluster; MED, medial glomerular cluster; $M O B$, main $0 B$; $O N$, olfactory nerve; $A$, anterior; $P$, posterior; $L$, lateral; $M$, medial.

A clear location-specific separation of axon bundles is visible in the olfactory nerve (Fig. 1A), but in the main OB partially overlapping axonal projections are apparent. In some cases, axon terminals originating from different topographical locations in the MOE do even converge into the same glomerulus (Fig. 1B).

\section{Axons of receptor neurons bifurcate in the main and the accessory olfactory system}

By changing electroporation parameters (e.g., higher patch pipette resistances), the number of labeled receptor neurons was reduced to few or single cells (Fig. $2 A-C$ ). Figure $2 D$ shows the $\mathrm{OB}$ structure (green axons) and a single labeled ORN (red axon). Two additional axons of VRNs projecting into the accessory $\mathrm{OB}$ (orange) were labeled by an additional electroporation in the vomeronasal organ (VNO). The single axon in the main OB bifurcated and eventually ended in tufted arborizations in two different glomeruli (Fig. 2E). The investigated ORNs entering the main $\mathrm{OB}(n=20)$ had $1.9 \pm 0.3$ branching points before terminating in $2 \pm 0.2$ tufted areas/glomeruli. The mean distance between the connected glomeruli was $48 \pm 5 \mu \mathrm{m}$. In larval X. laevis, individual glomeruli are relatively small, having mean diameters in the range of $\sim 20 \mu \mathrm{m}$ (Nezlin and Schild, 2000; Manzini et al., 2007). Figure $2 F$ shows another labeled ORN that featured three axonal bifurcations, resulting in four axon terminals that eventually innervated two glomeruli. To investigate the organization of the glomerular connections in the accessory $\mathrm{OB}$, we labeled axons of individual larval VRNs. Figure $2 G$ depicts a bundle of VRN axons entering the accessory $\mathrm{OB}$ and outlining its structure. Staining of fewer VRNs clearly showed that VRNs feature comparable axon growth patterns as ORNs in the main olfactory system. Axons of VRNs regularly bifurcated before entering two or more glomeruli (Fig. $2 \mathrm{H}$ ). The observed number of $2 \pm 0.2$ 

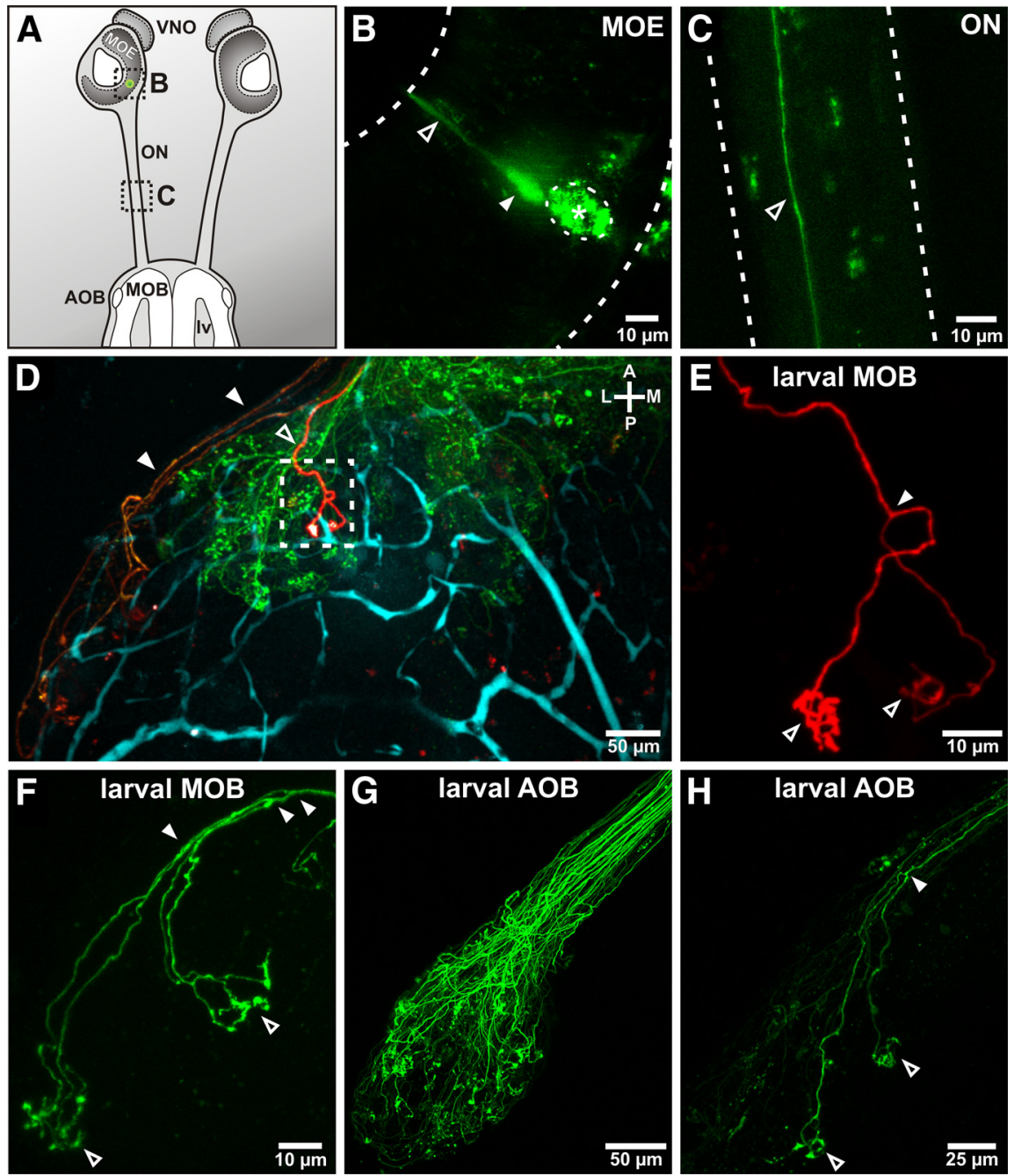

Figure 2. ORNs of the larval main and the accessory olfactory system feature bifurcated axonal growth patterns with multiple target glomeruli. $A$, Schematic representation of the larval olfactory system of X. laevis. Applying spatially restricted electroporation in the MOE (green circle), single ORNs were labeled. The dashed rectangles represent the locations of the detailed views in $\boldsymbol{B}$ and $\boldsymbol{C}$. $\boldsymbol{B}$, Representative example of a stained ORN (filled arrowhead) after electroporation. A dendrite protruding into the nasal cavity is visible (open arrowhead). The insertion site of the electroporation pipette is marked by an asterisk and a dashed circle. $\boldsymbol{C}$, The axons of labeled ORNs can be visualized and followed through the ON (open arrowhead). $\boldsymbol{D}$, The axonal growth pattern of a single labeled ORN (red, open arrowhead) can be visualized in the $\mathrm{OB}$; green represents all axons of the main $\mathrm{OB}$; blue, blood vessels. Also, two VRNs from a separate electroporation in the VNO are labeled in the accessory OB (orange represents filled arrowheads). $\boldsymbol{E}$, The depicted ORN ( $\boldsymbol{D}$, dashed rectangle) splits into two axon terminals (filled arrowheads) that terminate in two separate glomeruli (open arrowheads). $\boldsymbol{F}$, Example of an ORN with three branching points (filled arrowheads) before terminating in two distant tufted glomerular structures (open arrowheads). $\mathbf{G}$, Multiple labeled VRNs reveal the structure of the accessory $0 B$. $\boldsymbol{H}$, VRNs show comparable axon growth patterns to ORNs of the main OB. The VRN depicted shows a bifurcated axonal growth pattern (filled arrowhead) before entering two different glomeruli (open arrowheads). Iv, Lateral ventricle.

branching points before connecting to $2 \pm 0.2$ glomeruli $(n=27)$ did not differ significantly from main OB axons. Also, the mean distance of $50 \pm 5 \mu \mathrm{m}$ between the innervated glomeruli was comparable. Remarkably, ORNs and VRNs connected to only one glomerulus also usually featured one axon bifurcation, with the axon branches entering the glomerulus from different directions. Of all investigated neurons in larval specimen, only one cell grew an unbranched axon into a single-target glomerulus.

\section{Multiple glomerular connections of single axons are not limited to immature ORNs}

To find whether the observed axonal growth patterns are restricted to immature, growing ORNs, not yet stably connected to their target glomeruli, we conducted a series of in vivo time-lapse larval

imaging experiments. The axon growth patterns of single ORNs were monitored for $14 \pm 2 \mathrm{~d}$ on average in the main OB of larval $X$. laevis. In the course of these experiments, we identified two main subpopulations of ORNs. One subgroup consisted of immature ORNs with growing axons and no or only incomplete connections to glomeruli. These axons exhibited considerable morphological changes over time. A second subgroup consisted of ORNs already stably connected to their target glomeruli. An example of an immature ORN is depicted in Figure 3A-C. Twenty-four hours after labeling (Fig. $3 A$, day 1), its axon did not feature any extended tufted areas, indicating the absence of synaptic connections within glomeruli. The growing axon already showed multiple branching points and multiple axon endings spread over the OB. During maturation, the axon arborized considerably; and eventually, $10 \mathrm{~d}$ after staining, different branches reached at least two glomeruli (Fig. 3B, day 10, tufted axonal arborizations). Three-dimensional reconstructions of different time points of development illustrate the process of axon outgrowth and establishment of glomerular connections of this neuron (Fig. 3C). An example of an ORN with already established connections to two different glomeruli, $24 \mathrm{~h}$ after staining, is depicted in Figure 3D. The connection to the two glomeruli remained stable over a time of $16 \mathrm{~d}$, even though a refinement of intraglomerular arborizations and synaptic contacts was detected (Fig. 3E). Over the surveyed time period, the mean axon length of all investigated ORNs $(n=10)$ was $316 \pm 26 \mu \mathrm{m}$, with an average growth per day of $6 \pm 5 \mu \mathrm{m}$. The mean volume of glomerular tufts of all ORNs was $1077 \pm 26 \mu \mathrm{m}^{3}$, which slightly decreased in size by $34 \pm 23 \mu \mathrm{m}^{3}$ per day. On average, the initial axon length and size of glomerular tufts of the surveyed ORNs did not change significantly during the observed time span (Fig. 3F). Nevertheless, there was a tendency of axon elongation and glomerular tuft volume reduction. Also, the mean initial number of bifurcations and number of glomeruli of the surveyed ORNs of both subgroups did not change significantly during the observed time span (Fig. 3F).

\section{Bifurcating axons innervating multiple glomeruli persist in} the postmetamorphic olfactory system

In a last step, we investigated whether the atypical larval axonal growth patterns of ORNs and VRNs persist also in postmetamorphic animals. To address this question, we labeled receptor neurons of both the main and the accessory olfactory system of postmetamorphic X. laevis. Axons of both ORNs and VRNs showed extensive branching in the main and accessory OB. As in its larval stages, the large majority of axons of postmetamorphic receptor neurons innervated multiple glomeruli (Fig. $4 A-C, E$ ). 

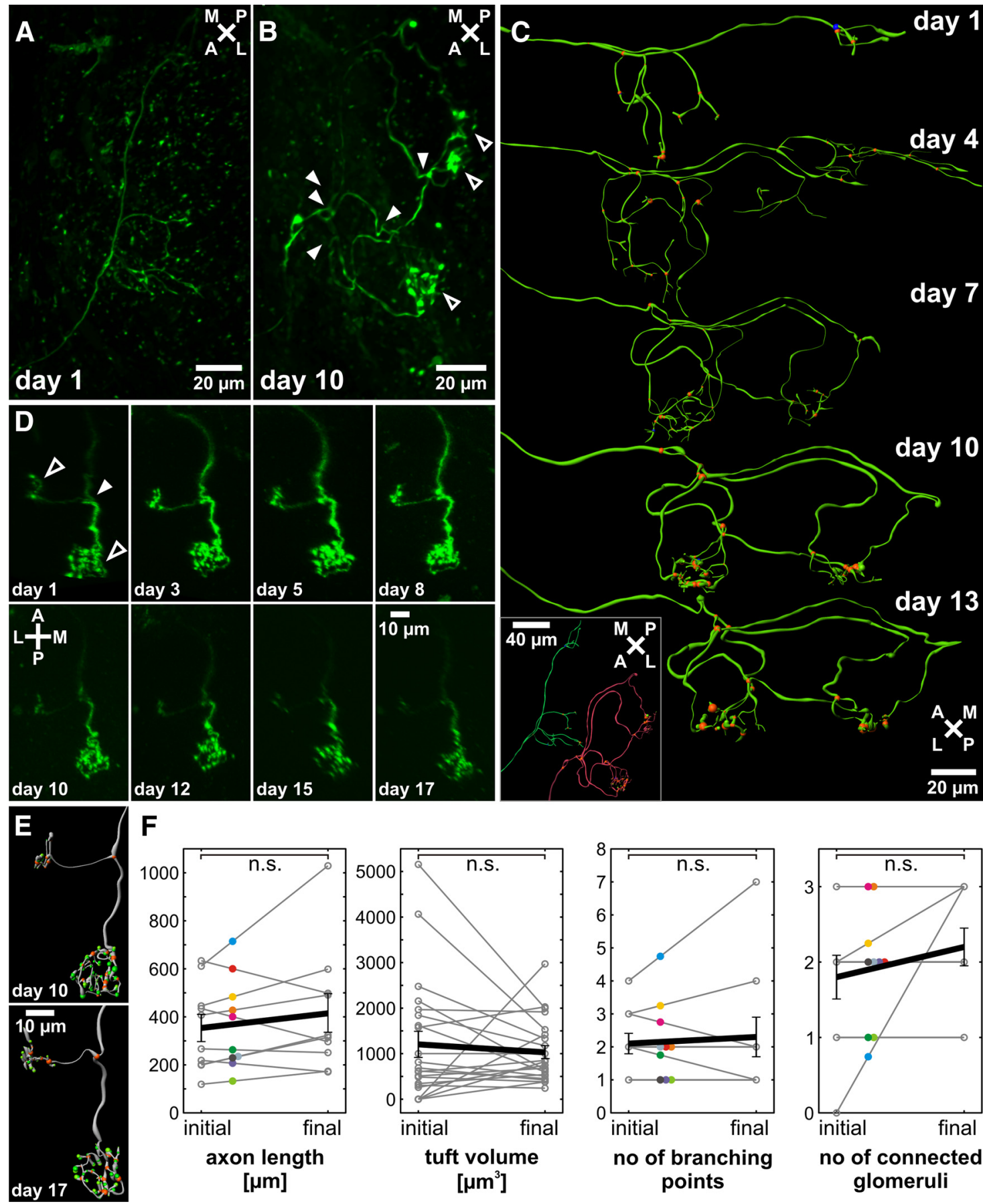

Figure 3. Repeated in vivo time-lapse imaging of single identified ORNs of larvae reveals no reduction of bifurcations or number of connected glomeruli during neuronal maturation. $A$, A single-labeled, immature ORN growing into the $0 B$ shows a number of branching points but lacks tufted arborizations characteristic for glomerular innervations. $\boldsymbol{B}$, The same 0 RN after $10 \mathrm{~d}$ shows extensive axon growth with multiple branching points (filled arrowheads) and multiple established connections to at least two different glomeruli (open arrowheads). C, Three-dimensional reconstructions of multiple recordings of the same ORN depicted in $\boldsymbol{A}$ and $\boldsymbol{B}$ illustrate the process of axonal outgrowth and glomerular innervation (orange represents branching points). Inset, Comparison of the recordings on day 1 (green) and day 10 (red). D, Time series of a mature ORN with one branching point (filled arrowhead) and established connections to two different glomeruli (open arrowhead). The axonal growth pattern does not change over the observed time of $16 \mathrm{~d}$. $\boldsymbol{E}$, Three-dimensional reconstructions of the cell depicted in $\boldsymbol{D}$ (one week distance). Inside the glomeruli, the axon arborizes multiple times (orange represents branching points), and synaptic contacts characterized by axonal thickenings can be identified (green). Whereas the rough axonal growth pattern is retained, intraglomerular connections are refined. $\boldsymbol{F}$, Quantitative comparison of axonal length, tuft volume, branching points, and connected glomeruli in the initial and the final state $(n=10)$. Error bars indicate SEM; statistical significance was tested using a paired $t$ test. Same cells are indicated by colored dots. Mean initial and final values are connected by a black line. n.s., Not significant.

The axons of the postmetamorphic main OB split $1.4 \pm 0.2$ times before terminating in $1.9 \pm 0.2$ glomeruli. These data were not significantly different from the data derived from larval animals (Fig. $4 D, n=20$ ). The connected glomeruli in the postmetamorphic main $\mathrm{OB}$ had a mean distance of $50 \pm 6 \mu \mathrm{m}$. The axons of the postmetamorphic accessory OB split $1.8 \pm 0.3$ times before terminating in $1.8 \pm 0.3$ glomeruli. These data were also not significantly different from the data derived from larval animals (Fig. $4 D, n=4$ ). The mean distance of the connected glomeruli in the postmetamorphic accessory $\mathrm{OB}$ was $88 \pm 14 \mu \mathrm{m}$. 

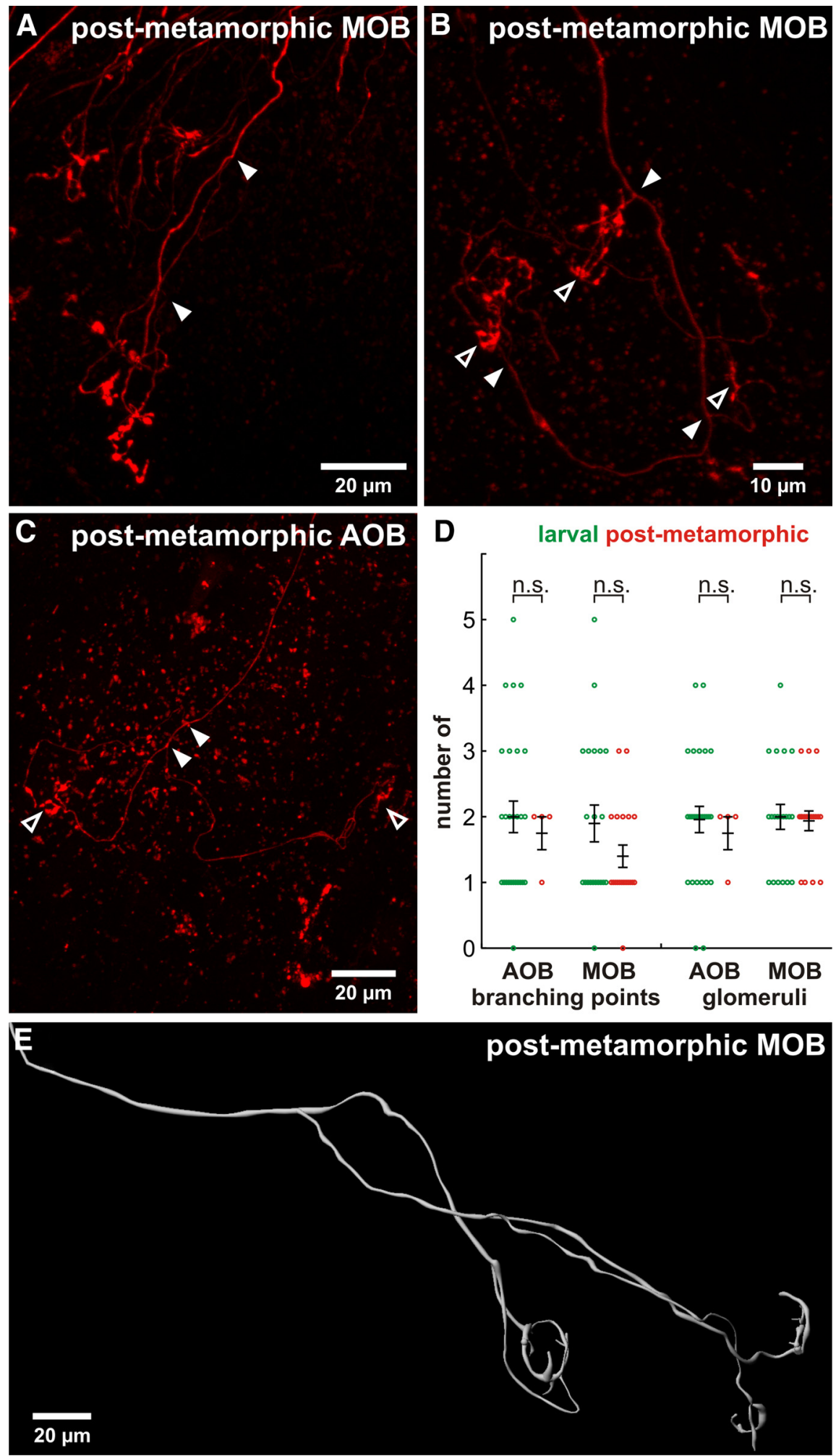

Figure 4. Postmetamorphic animals still possess branched receptor neuron axons with multiple glomerular connections Axonal bifurcations and multiglomerular innervations persist both in the postmetamorphic main olfactory $\operatorname{system}(\boldsymbol{A}, \boldsymbol{B})$ and accessory olfactory system $(\boldsymbol{C})$. Filled arrowheads indicate axonal branching points; open arrowheads indicate connections to glomeruli. $D$, Comparison of average axonal branching points and connected glomeruli in the larval $(n=27)$ and postmetamorphic accessory $\mathrm{OB}(n=4)$, and the larval $(n=21)$ and postmetamorphic main $\mathrm{OB}(n=20)$. Error bars indicate SEM; statistical significance was tested using an unpaired $t$ test. n.S., Not significant. $\boldsymbol{E}$, Three-dimensional reconstruction of an axon bifurcating three times before ending in three separate tufted glomerular structures.

\section{Discussion}

The wiring principles of olfactory systems are thought to be very similar in all vertebrate species, from fish to mammals. The consensus view is that receptor neurons send single unbranched axons to single glomeruli in the OB (Klenoff and Greer, 1998; for review, see Lodovichi and Belluscio, 2012). This particular anatomical connection between olfactory epithelia and $\mathrm{OB}$ constitutes the basic wiring logic of vertebrate olfactory systems. Each glomerulus with its associated ORNs forms an anatomical olfactory unit, representing the bulbar projection of a single OR. The so formed chemotopic odor map constitutes the basis of the coding logic of the main olfactory system and is thought to be the anatomical substrate for odor quality identification (Wang et al., 1998). Together, this shows that the chemotopic map generates a precise spatial code where single or very few glomeruli encode the olfactory information of a single OR.

Vomeronasal receptor neurons, expressing the same VR, project into numerous glomeruli in the accessory $\mathrm{OB}$ (Del Punta et al., 2002). This means that, in the accessory olfactory system, a more vague spatial code is formed, with numerous glomeruli corresponding to a single VR.

In contrast to the situation in all vertebrate species so far investigated, axons of single-receptor neurons of both the main and accessory olfactory system of Xenopus are mostly connected with two or more glomeruli. This is restricted neither to immature ORNs nor to a specific ontogenetic larval phase (compare Nezlin and Schild, 2005) but is retained also in postmetamorphic frogs, excluding that the observed projections patterns are a developmental feature. This allows the general assumption that the basic anatomical units of the Xenopus olfactory system are dramatically different than in any other species studied so far. Thus, the chemotopic maps in both olfactory subsystems of Xenopus form rather vague spatial codes in the $\mathrm{OB}$, with multiple glomeruli receiving input from single-receptor neurons. If receptor neurons associated with the same OR/VR always innervate the same glomeruli, the underlying coding logic would not substantially differ from the main olfactory system of rodents (Mombaerts, 2006). It remains to be clarified whether, in Xenopus, different individual receptor neurons have coincident glomerular innervation patterns.

On the other hand, the situation in $\mathrm{Xe}$ nopus could be similar to what has been 
reported for the rodent accessory olfactory system, where the chemotopic map also generates a more vague spatial code with numerous glomeruli corresponding to single VRs. But unlike in Xenopus, single VRNs in the rodent accessory system project unbranched axons into single glomeruli. Individual mitral cells in the rodent accessory $\mathrm{OB}$ extend dendrites to multiple glomeruli associated with single or multiple, but presumably closely related, VRs (Wagner et al., 2006; Meeks et al., 2010). It has also been shown that mitral cells of larval $X$. laevis regularly innervate multiple glomeruli (Nezlin and Schild, 2005). This raises the question of whether Xenopus mitral cells exclusively collect information from all glomeruli innervated by single ORNs/VRNs or whether they integrate information from neuronal populations expressing different ORs/VRs.

Interestingly, in earlier diverging vertebrates (fishes), the wiring and coding logic resemble those in rodents (Holmgren, 1920; Dynes and Ngai, 1998). This suggests that the primordial axonal wiring pattern in the olfactory system of fishes has evolved to the bifurcated pattern in the amphibian lineage, but not in the lineage leading to mammals.

The loss of a precise spatial code in the OB of Xenopus could have been favored by the fact that the sense of smell seems to play a minor role in amphibians (Jørgensen, 2000). Especially in anuran amphibians, acoustic and not chemosensory signals are thought to be the primary path of intraspecific communication. On the other hand, in many amphibian species, including $X$. laevis, olfaction has been shown to play an important role in the search for food, migration, and orientation (Jørgensen, 2000). The vague spatial code in the OB of Xenopus could be an indication that its olfactory system is not built to sense and differentiate between many different olfactory stimuli but rather carries the information of a few broad groups of stimuli possibly driving some fundamental behavioral patterns. It has been shown that larval X. laevis have spatially segregated odor processing streams carrying information of broad odor groups (Gliem et al., 2013). On the other hand, Xenopus possesses a large number of ORs and VRs (Ji et al., 2009; Shi and Zhang, 2009) and its OB has $~ 800$ glomeruli (Manzini et al., 2007). As a few broad odorant groups could be coded by relatively few receptors and glomeruli, the question arises why the Xenopus olfactory system has conserved so many receptors and glomeruli during evolution.

As a last point, we would like to discuss the possibility that in Xenopus individual receptor cells could express more than one OR or VR. This could explain the observed axonal projection pattern of individual receptor neurons into more than one glomerulus. The possibility of polygenic olfactory receptor expression in single ORNs of Xenopus has already been extensively discussed (Manzini and Schild, 2004; Restrepo, 2004).

Together, this work shows that the view that receptor neurons send a single, unbranched axon into a single glomerulus can no longer be generalized for all vertebrates. It will require further studies to find whether the described wiring pattern is typical for amphibian species in general and whether it exists also in other vertebrate species. It will also be exciting to elucidate the odorant detection and olfactory coding strategy of $X$. laevis, taking into account the described axonal wiring pattern.

\section{References}

Chess A, Simon I, Cedar H, Axel R (1994) Allelic inactivation regulates olfactory receptor gene expression. Cell 78:823-834. CrossRef Medline

Coupé P, Munz M, Manjón JV, Ruthazer ES, Collins DL (2012) A CANDLE for a deeper in vivo insight. Med Image Anal 16:849-864. CrossRef Medline

Del Punta K, Puche A, Adams NC, Rodriguez I, Mombaerts P (2002) A divergent pattern of sensory axonal projections is rendered convergent by second-order neurons in the accessory olfactory bulb. Neuron 35:10571066. CrossRef Medline

Dryer L, Graziadei PP (1994) Mitral cell dendrites: a comparative approach. Anat Embryol (Berl) 189:91-106. Medline

Dynes JL, Ngai J (1998) Pathfinding of olfactory neuron axons to stereotyped glomerular targets revealed by dynamic imaging in living zebrafish embryos. Neuron 20:1081-1091. CrossRef Medline

Eisthen HL (1992) Phylogeny of the vomeronasal system and of receptor cell types in the olfactory and vomeronasal epithelia of vertebrates. Microsc Res Tech 23:1-21. CrossRef Medline

Gliem S, Syed AS, Sansone A, Kludt E, Tantalaki E, Hassenklöver T, Korsching SI, Manzini I (2013) Bimodal processing of olfactory information in an amphibian nose: odor responses segregate into a medial and a lateral stream. Cell Mol Life Sci 70:1965-1984. CrossRef Medline

González A, Morona R, López JM, Moreno N, Northcutt RG (2010) Lungfishes, like tetrapods, possess a vomeronasal system. Front Neuroanat 4:130. CrossRef Medline

Haas K, Jensen K, Sin WC, Foa L, Cline HT (2002) Targeted electroporation in Xenopus tadpoles in vivo: from single cells to the entire brain. Differentiation 70:148-154. CrossRef Medline

Holmgren N (1920) Zur Anatomie und Histologie des Vorder-und Zwischenhirns der Knochenfische. Acta Zool 1:137-315. CrossRef

Ishii T, Mombaerts P (2011) Coordinated coexpression of two vomeronasal receptor V2R genes per neuron in the mouse. Mol Cell Neurosci 46:397408. CrossRef Medline

Ji Y, Zhang Z, Hu Y (2009) The repertoire of G-protein-coupled receptors in Xenopus tropicalis. BMC Genomics 10:263. CrossRef Medline

Jørgensen CB (2000) Amphibian respiration and olfaction and their relationships: from Robert Townson (1794) to the present. Biol Rev Camb Philos Soc 75:297-345. CrossRef Medline

Klenoff JR, Greer CA (1998) Postnatal development of olfactory receptor cell axonal arbors. J Comp Neurol 390:256-267. CrossRef Medline

Komiyama T, Luo L (2006) Development of wiring specificity in the olfactory system. Curr Opin Neurobiol 16:67-73. CrossRef Medline

Lodovichi C, Belluscio L (2012) Odorant receptors in the formation of the olfactory bulb circuitry. Physiology (Bethesda) 27:200-212. CrossRef Medline

Malnic B, Hirono J, Sato T, Buck LB (1999) Combinatorial receptor codes for odors. Cell 96:713-723. CrossRef Medline

Manzini I, Schild D (2004) Classes and narrowing selectivity of olfactory receptor neurons of Xenopus laevis tadpoles. J Gen Physiol 123:99-107. CrossRef Medline

Manzini I, Heermann S, Czesnik D, Brase C, Schild D, Rössler W (2007) Presynaptic protein distribution and odour mapping in glomeruli of the olfactory bulb of Xenopus laevis tadpoles. Eur J Neurosci 26:925-934. CrossRef Medline

Marcucci F, Maier-Balough E, Zou DJ, Firestein S (2011) Exuberant growth and synapse formation of olfactory sensory neuron axonal arborizations. J Comp Neurol 519:3713-3726. CrossRef Medline

Meeks JP, Arnson HA, Holy TE (2010) Representation and transformation of sensory information in the mouse accessory olfactory system. Nat Neurosci 13:723-730. CrossRef Medline

Mombaerts P (2006) Axonal wiring in the mouse olfactory system. Annu Rev Cell Dev Biol 22:713-737. CrossRef Medline

Nezlin LP, Schild D (2000) Structure of the olfactory bulb in tadpoles of Xenopus laevis. Cell Tissue Res 2000 302:21-29. Medline

Nezlin LP, Schild D (2005) Individual olfactory sensory neurons project into more than one glomerulus in Xenopus laevis tadpole olfactory bulb. J Comp Neurol 481:233-239. CrossRef Medline

Nieuwkoop PD, Faber J (1994) Normal table of Xenopus laevis (Daudin). New York: Garland.

Restrepo D (2004) What the frog's nose tells the frog's brain. J Gen Physiol 123:97-98. CrossRef Medline

Shatz CJ (1996) Emergence of order in visual system development. Proc Natl Acad Sci U S A 93:602-608. CrossRef Medline

Shi P, Zhang J (2009) Extraordinary diversity of chemosensory receptor gene repertoires among vertebrates. Results Probl Cell Differ 47:1-23. CrossRef Medline

Wagner S, Gresser AL, Torello AT, Dulac C (2006) A multireceptor genetic approach uncovers an ordered integration of VNO sensory inputs in the accessory olfactory bulb. Neuron 50:697-709. CrossRef Medline

Wang F, Nemes A, Mendelsohn M, Axel R (1998) Odorant receptors govern the formation of a precise topographic map. Cell 93:47-60. CrossRef Medline 